\title{
SUSTAINABLE PRODUCTS IN THE LEATHER INDUSTRY
}

\author{
OLGA BALLUS ${ }^{1}$, ANNA BACARDIT ${ }^{2}$ \\ ${ }^{1}$ Cromogenia Units S.A, C/ Feixa Llarga 1-3 Pol. Ind. Zona Franca, 08040 Barcelona, \\ oballus@cromogenia.com \\ ${ }^{2}$ Departament d'Informàtica i Enginyeria Industrial, Universitat de Lleida, Campus Universitari \\ d'Igualada, Av. Pla de la Mass 8,08700Igualada,anna.bacardit@udl.cat
}

\begin{abstract}
Protecting the environment is one of the three objectives of sustainability. One way to achieve this is to preserve natural resources by using renewable or residual raw materials. These products have a shorter lifespan and a lower carbon footprint, are highly biodegradable, and are therefore considered to be sustainable products. In this paper, three retanning agents and two oils classified as sustainable products were studied. First, biobased carbon content (an indicator of renewable raw material content) was determined. Then, the physical and organoleptic properties of the leathers treated with each product (degree of softness, firmness and fullness) were evaluated. The COD of residual baths was also determined in oils. The products presented in this paper meet the sustainability requirements, i.e., high renewable raw material content, short lifespan, and low carbon footprint. In addition, these products show high fixation and therefore have a low COD in residual baths, thus also contributing to their sustainability.
\end{abstract}

Keywords: Sustainable products, bio-based products, leather industry

\section{INTRODUCTION}

The transformation of an animal's skin into leather is known as a tanning process. This process includes a series of physical-chemical transformations that turn the skin into a durable and usable material. This process is divided into four main stages: beamhouse, tanning, retanning and finishing. In the beamhouse stage, the skin is hydrated and the hair and epidermis are removed. Then, leather is tanned, generally with chromium salts (wet blue) and to a lesser extent with aldehydes and/or vegetable extracts (wet white), to give stability to the collagen. The retanning stage also includes dyeing and fatliquoring and at this stage the properties and characteristics of the tanned leather are modified to obtain different types of articles. Finally, the finishing stage consists of applying surface treatments to the leather to achieve different properties such as gloss or physical resistances.

Sustainability in the leather industry is an important factor that has gained relevance in recent years. The definition of sustainability proposed in the Bruntland (Finkbeiner et al., 2010) report implies, among other things, maintaining a balance between the resources used and the waste dumped. In other words, avoiding the depletion of nonrenewable resources and avoiding the overexploitation of renewable resources, as well as reducing the discharge of pollutants to the environment.

Leather is a by-product of the meat and dairy industry, and if it is not transformed into leather, this by-product becomes a problematic waste, among other things due to the high volume (currently 10 million tons of leather are processed per year) (Buljan and Král', 2019). Hides and skins are therefore renewable resources and are considered sustainable products that contribute to the circular economy. However, the tanning process uses a high amount of water and chemicals that can affect both the environment and people's health. This must be studied in depth in order to contribute to the sustainability of the tanning process.

Currently most of the products used in the tanning process come from petroleum chemistry. Petroleum is a non-renewable resource and its treatment and use have a high contribution to climate change (Okkerse and Van Bekkum, 1999) and therefore great efforts are being devoted to the search for cleaner and more sustainable alternatives. 
In this work, various products used in the retanning and fatliquoring stage are proposed that contribute to the improvement of the sustainability of the leather. The products must meet the following characteristics: they must come from renewable resources thus they will have improved biodegradability (European Commission, 2009; http://www.biobasedinprocurement.eu, 2017), reduced danger to humans and the environment, highly effective and low COD in wastewater, and they do not contain restricted substances. For this, two acrylic-based and one phenolic-based retanning products have been designed in which part of the acrylic/phenolic base have been replaced by biopolymers from renewable resources: proteins and polysaccharides and two oils based on natural raw materials: fish and soy derivatives.

\section{EXPERIMENTAL}

Three retanning agents (two acrylic-based and one phenolic-based) and two fatliquoring agents were studied (Table 1). All products contain raw material from renewable resources.

Table 1. Products, nature, active matter

\begin{tabular}{lcc}
\hline Product & Nature & Active matter \\
\hline PRODUCT ST-AA & Acrylic & $27 \%$ \\
PRODUCT ST-A2P & Acrylic & $30 \%$ \\
PRODUCT ST-MP & Phenolic & $95 \%$ \\
PRODUCT ST-AW & Oil of natural origin & $90 \%$ \\
PRODUCT ST-AF & Oil of natural origin & $70 \%$ \\
\hline
\end{tabular}

\section{Biobased Content Analysis}

Percentage of biobased carbon was determined by ASTM D6866-18 Method B (AMS) to determine the raw material derived from renewable resources. The reference standard for C14 measurements is NIST 4990C.

\section{Leather Application}

Hides were divided into $40 \times 100 \mathrm{~cm}$ pieces for each product.

Wet blue tanned leathers of Spanish origin split at 1.4-1.5 mm were used to evaluate the retanning agents. Retanning products were applied at $5 \%$ after leather neutralization at $\mathrm{pH}$ 5.5. Fatliquoring and dyeing were performed according to a standard formulation. Wet blue tanned leathers of Spanish origin split at $1.0-1.1 \mathrm{~mm}$ were used to evaluate fatliquoring agents. Leathers were neutralized at pH 6.5 and fatliquored by applying $10 \%$ of the oil in a separate bath. Retanning and dyeing were performed according to standard formulation.

\section{Bath and Hide Determinations}

Chemical oxygen demand (COD) of the residual baths was determined. Analysis were performed with $1-1500 \mathrm{mg} / \mathrm{L}$ vials heated under reflux for 2 hours at $150^{\circ} \mathrm{C}$, and COD was measured with an Aqualytic AL100 spectrophotometer.

After retanning, color intensity and physical properties were determined. The degree of softness was determined according to IUP 36, thickness according to IUP 4 and firmness by SATRA PM 36 scale. In order to assess the dyeing properties of the different products used, dyeing intensity was measured with a Color Data Spectraflash SF-30 colorimeter. 
RETANNING AGENTS

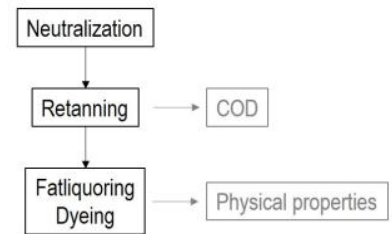

FATLIQUORING AGENTS

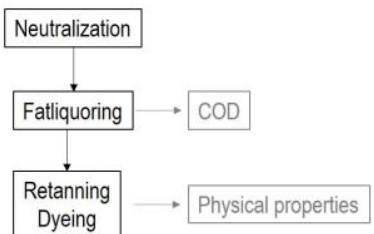

Figure 1. Scheme of application formulation

\section{RESULTS AND DISCUSSION}

\section{Products}

\section{Acrylic Polymers}

Acrylic polymers are widely used as retanning agents. These products provide high firmness, they are very well fix to the leather and have good fastnesses. Acrylic resins are polymers from the acrylic acid, and the standard products are $100 \%$ derived from petroleum. To improve the sustainability of these products, biopolymers have been reacted with the acrylic resins. The synthesis is based on a radical polymerization of the acrylic acid with biopolymers (BP) derived from proteins and polysaccharides. Reaction is shown in Figure 2.

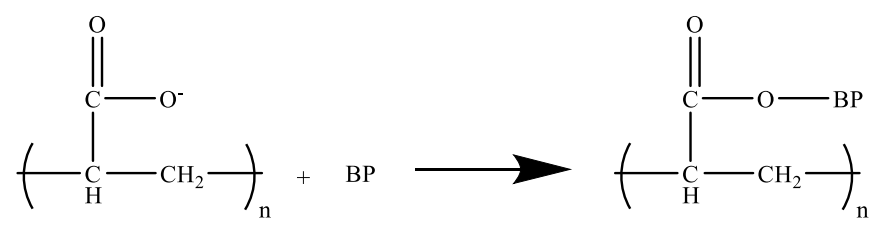

Figure 2. Scheme of application formulation

\section{Phenolic Polymer}

Phenolic polymers are used in the retanning stage to increase leather fullness, among other properties. These products are obtained trough a condensation reaction of phenol and formaldehyde. Basic structure of these polymers is shown in Figure 3.

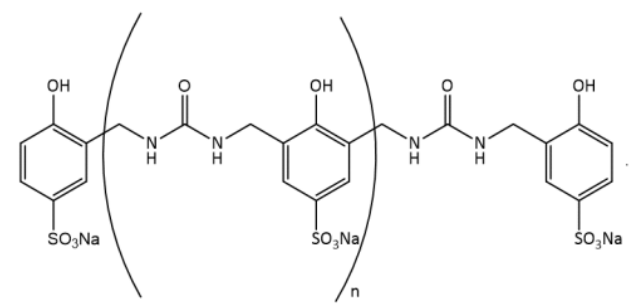

Figure 3. Phenolic retanning polymer structure

These products are $100 \%$ petroleum derivatives and they are considered non sustainable products. To improve its sustainability, biopolymers from different origins can be added during the condensation phase. In this work, lignin and protein derivatives 
were added during the condensation stage so they can form polymeric bonds and a biopolymer of high molecular weight is obtained.

\section{Fatliquoring Agents}

Fatliquoring agents can come from petroleum derivatives such as mineral oils or sulphochlorinated paraffins. They can also come from natural fat (animal and vegetal) and are mainly form by triglycerides. Triglycerides are treated first with oxygen and with bisulfite to obtain water soluble products. Sulphitation reaction is shown in Figure 4.<smiles>CCc1cc([N+](=O)[O-])ccc1O</smiles>

Figure 4. Sulphitation reaction of triglycerides

Fatliquoring products are usually combinations of both products, mineral and synthetic. In this work we developed two fatliquoring agents with high biobased carbon content that can give similar characteristics as the standard products: PRODUCT STAW and PRODUCT ST-AF.

\section{Renewable Source Determination}

Carbon-14 analysis is used to determine the percentage of biobased carbon in a product, that is, the carbon from renewable animal or plant resources.

Results are reported as \% biobased carbon. A value of $100 \%$ biobased would indicate that all carbon content comes from renewable sources (plants or animals byproducts) and a value of $0 \%$ would point that all of the carbon of the sample was derived from non-renewable sources (petrochemicals, coal and other fossil sources). Values between these two proportions would mean that there is a mixture, where the higher the percentage, the greater the proportion of renewable raw material in the sample and therefore higher sustainability of the product.

The percentage of biobased carbon of the retanning agents is showed in Figure 5. RETANAL ST-MP has the highest value of C14 content followed by RETANAL STA2P and RETANAL ST-AA.
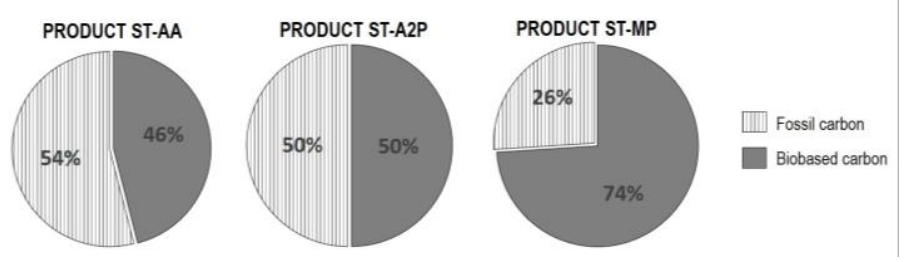

Figure 5. Bio-based carbon content of retanning agents

The percentage of biobased carbon of fatliquoring agents are shown in Figure 6. In this case, the two products show that most of the carbon contained in the product is biobased, that is, from sustainable sources. 

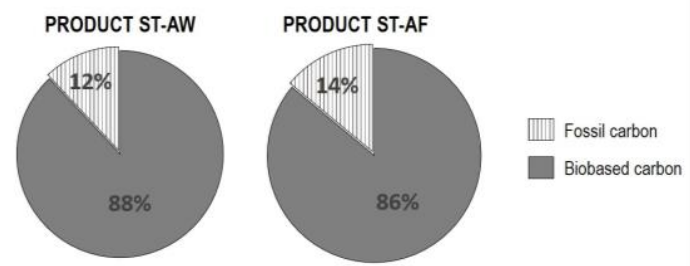

Figure 6. Bio-based carbon content of fatliquoring agents

\section{Assessment of Properties}

Depending on the final leather article (upholstery, garment, etc) different products are selected. Standard processes always have a combination of retanning agents from different nature (acrylic, phenolic, sulfones, vegetables, etc) as well as oils of different nature (animal or vegetable origin, sulfited, sulphated, etc) in order to provide the best characteristics to the leather such as fullness, softness, physical resistances, etc.

To evaluate the performance of the retanning agents, a comparison of the sustainable products was made with respect to a reference sample (non-renewable acrylic and phenolic product). COD of the baths were analyzed at the end of the retanning stage to evaluate the fixation of the products and different properties such as thickness, softness firmness and dyeing intensity were assessed after fatliquoring and dyeing.

Table 2 shows the results of COD and physical properties expressed as a percentage variation of sustainable products versus non-renewable products.

Table 2. COD and physical properties

\begin{tabular}{lcccc}
\hline Product & COD & Softness & Thickness & Firmness \\
\hline PRODUCT ST-AA & $-20 \%$ & $+30 \%$ & $0 \%$ & $0 \%$ \\
PRODUCT ST-A2P & $-30 \%$ & $-25 \%$ & $-20 \%$ & $-15 \%$ \\
PRODUCT ST-MP & $-20 \%$ & $+20 \%$ & $-15 \%$ & $-20 \%$ \\
\hline
\end{tabular}

In all cases, there is a decrease in COD values for sustainable products. Softness is improved (except for PRODUCT ST-A2P), but thickness and firmness are slightly worse for PRODUCT ST-A2P and PRODUCT ST-MP. PRODUCT ST-AA improves all characteristics.

COD values of sustainable oils are compared versus a lecithin-based oil as a reference. Table 3 shows the results as a percentage variation of the sustainable fatliquors versus the reference.

Table 3. COD and physical properties

\begin{tabular}{lcccc}
\hline Product & COD & Softness & Thickness & Firmness \\
\hline PRODUCT ST-AW & $-60 \%$ & $+10 \%$ & $0 \%$ & $0 \%$ \\
PRODUCT ST-AF & $-25 \%$ & $+25 \%$ & $-10 \%$ & $-15 \%$ \\
\hline
\end{tabular}

There is a reduction in COD values of sustainable products, which indicates that products are well fixed in the leather and baths contain less pollutants.

Softness is improved for both products PRODUCT ST-AW and PRODUCT ST-AF with respect to the reference product, but firmness is similar for PRODUCT ST-AW and slightly lower for PRODUCT ST-AF. 
Dyeing intensity was measured by colorimeter and color levelness was evaluated organoleptically. Both characteristics are expressed in a 1-5 scale (in ascending order). Results for all products are shown in Table 4.

Table 4. Color intensity and color levelness

\begin{tabular}{lcc}
\hline Product & Intensity & Levelness \\
\hline PRODUCT ST-AA & 3 & 5 \\
PRODUCT ST-A2P & 5 & 4 \\
Acrylic standard & 2 & 5 \\
PRODUCT ST-MP & 4 & 5 \\
Phenolic standard & 2 & 5 \\
PRODUCT ST-AW & 2 & 4 \\
PRODUCT ST-AF & 4 & 3 \\
Standard fatliquor & 2 & 4 \\
\hline
\end{tabular}

PRODUCT ST-AA and PRODUCT ST-A2P improve color intensity and provide similar color levelness as the standard acrylic product.

PRODUCT ST-MP provides similar color levelness as the phenolic standard and better dyeing intensity.

PRODUCT ST-AW has similar characteristics as its reference regarding dyeing intensity and color levelness, while PRODUCT ST-AF improves color intensity and reduces color levelness.

\section{CONCLUSIONS}

Several retanning and fatliquoring products with sustainable characteristics have been developed. These products meet the following characteristics: they have a high percentage of biobased carbon $(\geq 50 \%)$, which indicates that the product comes mainly from renewable sources, they have higher fixation (lower COD in wastewater than standard products) and they do not contain restricted substances. Compared to standard products, sustainable products provide similar characteristics to the leather.

\section{REFERENCES}

Adzet, J.M. (1985), Química Técnica de Tenería. Igualada: Romanyà/Valls.

Buljan, J. and Král', I. (2019), "The Framework for Sustainable Leather Manufacture Second Edition," 27, https://leatherpanel.org.

European Commission (2009), "Taking Bio-Based from Promise to Market - Measures to Promote the Market Introduction of Innovative Bio-Based Products," 28, https://doi.org/10.2769/34881.

Finkbeiner, M., Schau, E.M., Lehmann, A. and Traverso, M. (2010), "Towards Life Cycle Sustainability Assessment", Sustainability, 2(10), 3309-22. https://doi.org/10.3390/su2103309.

Harris, J.M. (2003), "Sustainability and Sustainable Development", International Society for Ecological Economics, February: 1-12, available at: http://isecoeco.org/pdf/susdev.pdf.

Khan, M.A. (1995), "Sustainable Development: The Key Concepts, Issues and Implications. Keynote Paper given at the International Sustainable Development Research Conference, 27-29 March 1995, Manchester, UK", Sustainable Development, 3(2), 63-69, https://doi.org/10.1002/sd.3460030203.

Okkerse, C. and Van Bekkum, H. (1999), "From Fossil to Green", Green Chemistry, 1(2), 107-14 https://doi.org/10.1039/a809539f.

Sutton, P. (2004), “A Perspective on Environmental Sustainability?”, A paper for the Victorian Commissioner for Environmental Sustainability, available at: http://www.green-innovations.asn.au/APerspective-on-Environmental-Sustainability.pdf

Zimmerman, J.B., Anastas, P.T., Erythropel, H.C. and Leitner, W. (2020), "Designing for a Green Chemistry Future", Science, 367(6476), 397-400, https://doi.org/10.1126/science.aay3060.

*** (2017), "Bio-Based Products in Procurement How to Consider Innovative Bio-Based Products in Procurement.", July, http://www.biobasedinprocurement.eu/.

https://doi.org/10.24264/icams-2020.IV.3 